\title{
Study of the Effect of Different Irrigation and Conservation Tillage Practices on the Performance of Different Sugarcane Planter under NWPZ Conditions
}

\author{
Manish Kumar ${ }^{1 *}$, Ashok Tripathi ${ }^{2}$ and Mrinal Verma ${ }^{3}$ \\ ${ }^{1}$ Farm Machinery Testing Centre, College of Agricultural Engineering, Dr. Rajendra Prasad \\ Central Agriculture University, Pusa-(Samastipur) 848125, Bihar, India \\ ${ }^{2}$ Department of Farm Machinery and Power Engineering, VIAET, Sam Higginbottom \\ University of Agriculture, Technology and Sciences, \\ Allahabad - 211007, Uttar Pradesh, India \\ ${ }^{3}$ Krishi Vigyan Kendra, Patna- 803214 \\ (Bihar Agricultural University, Sabour Bhagalpur), India \\ *Corresponding author
}

A B S T R A C T

A field experiment was conducted for two consecutive years (2014-15 to 2015-16) at Amroha district of Uttar Pradesh State, India. Different sugarcane planter and conservation tillage practices were tested for intensification and productivity of sugarcane (Saccharum

Keywords

Sugarcane, Irrigation, Tillage, Planters, Ridger, disc

Article Info

Accepted: 22 April 2018 Available Online: 10 May 2018 officinarum L.) after wheat harvest in Fauladpur research farm of Amroha district in NWP region of Uttar Pradesh. After the analysis of the different treatment of the sugarcane production with the consideration of two irrigation planting field conditions (pre and postplanting irrigation), two tillage [Conventional tillage (1ploughing +2 harrowing) and Tillage operation by rotary tiller (2 rotavator)], four planters as Disc type sugarcane cutter planter, Slit type sugarcane cutter planter, Ridger sugarcane cutter planter, Furrower type sugarcane cutter planter and control as conventional practice. The maximum treatment effect of the effective field capacity and field efficiency of sugarcane in the Ridger sugarcane cutter planter was found during the years in comparison of the other planters. Maximum treatment effect of the field efficiency was found (58.63 and 58.275\%) during both year 2014-15 and 2015-16 respectively for Ridger sugarcane cutter planter. Seed rate and depth of planting was minimum for post planting irrigation and Tillage operation by rotary tiller (2 rotavator) during both year 2014-15 and 2015-16. Effective field capacity and field efficiency was maximum for post planting irrigation and Tillage operation by rotary tiller (2 rotavator) during both year 2014-15 and 2015-16.

\section{Introduction}

Sugarcane (Saccharum officinarum L.) crop is an important cash crop worldwide cultivated in 105 countries. Sugarcane has played an important role to improving socioeconomic status of human life from its ancient production to modern day's status. Sugarcane has a great economical importance for a farmer due to its versatile nature. Sugarcane is 
important crop for sugar because it contributes about $64.6 \%$ of sugar production. Sugarcane (Saccharum officinarum L.) is an important food cum cash crop and cultivated between $32^{0} \mathrm{~N}$ to $32^{0} \mathrm{~S}$ latitude covering more than 90 countries of the world (Kumar et al., 2017 a; Kumar and Tripathi, 2017c).

Sugarcane occupies a very prominent position on the agricultural map of India covering astronomically immense areas in sub-tropics and tropics (Kumar et al., 2017 b).

India is one of the highest producers of sweetener (sugar) and it has a tough competition with Brazil for the first rank. The India has shared about $13.25 \%$ of the World's and about $41.11 \%$ of Asian sugar production and sugarcane is cultivated in about $4.10 \mathrm{mn}$ hectares with the yearly production of about $300.25 \mathrm{mn}$ tons of sugarcane and $18.90 \mathrm{mn}$ tons of sugar. In India the major area under this crop presented in subtropical belt covering Uttar Pradesh, Bihar, Punjab, Uttarakhand, Haryana, Rajasthan and Madhya Pradesh; which used about $70 \%$ of the cane cultivated area and $50 \%$ of the sugarcane production. Sugarcane cultivated highly in Uttar Pradesh and Uttarakhand states which is jointly make $49.74 \%$ of the total cane area and about $44.34 \%$ of the total cane production in country.

Planting of sugarcane carried a number of operations such as cutting of canes into setts, tillage, furrows opening, use of fertilizer in the furrows, inserting setts and covering these open furrows with a blanket of soil. To suit the varying agro climatic conditions of different states, these operations are sometimes changed and modified and are performed either manually with help of animal drawn or tractor drawn ridge and sugarcane sets are placed and covered manually or by machinery. Thereafter, wooden planked is used to ensure better sett and soil moisture content.
The whole process of sugarcane planting is very labour and time intensive. In order to achieve uniform crop stand, correct seed rate, appropriate depth of setts placements and uniformity of setts with required overlapping are important. By using tractor-drawn sugarcane cutter planter, the economising labour and energy could be reduced. Planting of sugarcane is performed by cuttings setts from a mature plant of sugarcane, rather than from its seed. Although certain types of sugarcane varieties are still producing from the seeds, but the present methods of stem cuttings of mature sugarcane have become the most common method of reproduction of sugarcane. For this purpose, each cutting has at least one bud. There are various methods of the planting of sugarcane such as flat type, trench type, pit type, staggered row and spaced transplanting methods. Since, the cost of harvesting of sugarcane by mechanized process is almost one third of complete manual process. Thus cane cutter planters are getting good response by the farmers, due to the reduction of unit operations and man power (Kumar et al., 2015).

In the present era of labour shortage and unavailability of animal to do farm operations, there is an urgent need to mechanize sugarcane planting for reducing the cost as well as the human drudgery involved. Under conventional method, the sugarcane sett cutting process is a pre planting practice, while in mechanized system setts cutting is done simultaneously by the planter. This ultimately reduces time, labour and moisture loss in setts of cane and helps in higher germination percentage. Thus to reduce drudgery and cost of planting, efficient utilization of seed and fertilizer, use of planters is advocated. The cost of per tonns Rs. $\quad 77.55$ in mechanical harvesters (Vachaparampil 1999), while considering the fixed and operating costs the cost of mechanical harvesting ranges from Rs. 157 to 
194/tone (Anonymous 2001). Sugarcane planting involves 337.5 man-hours and 30.6 bullock pair hours with a cost of Rs. 3,987/ha land, while mechanical planting involves total cost Rs. 2,200/with the engagement of 20 man-hours. There was substantial reduction of labour requirement from 130 to 150 manhours per hectare (by conventional method) to 35-40 man-hours per hectare by machine planting (Yadav et al., 2001). Farm mechanization of sugarcane production is an essential thing to the modern agriculture, as it enhances better productivity, besides reducing human drudgery and cost of cultivation.

\section{Materials and Methods}

A field experiment was conducted for two consecutive years (2014-15 to 2015-16) at Amroha district of Uttar Pradesh State, India. Different sugarcane planter and conservation tillage practices were tested for intensification and productivity of sugarcane (Saccharum officinarum L.) after wheat harvest in Fauladpur research farm of Amroha district in NWP region of Uttar Pradesh. There were two irrigations, pre- planting irrigation $\left(\mathrm{I}_{1}\right)$ and post-planting irrigation $\left(\mathrm{I}_{2}\right)$, four planters as Disc type sugarcane cutter planter $\left(\mathrm{P}_{1}\right)$, Slit type sugarcane cutter planter $\left(\mathrm{P}_{2}\right)$, Ridger sugarcane cutter planter $\left(\mathrm{P}_{3}\right)$ and Furrower type sugarcane cutter planter $\left(\mathrm{P}_{4}\right)$ and control $\left(\mathrm{P}_{0}\right)$ as conventional practice, two tillage as $\left(\mathrm{T}_{1}\right)$ Conventional tillage (1 ploughing +2 harrowing) and Tillage operation by rotary tiller (2 rotavator) $\left(\mathrm{T}_{2}\right)$ were tested under RBD (Factorial $2 \times 5 \times 2$ ) with three replications. The control was the conventional practices of sugarcane planting (furrow opening by the tractor operated ridger and then manual sett placement in the furrows) as prevailing in the district. The plot size was $10 \mathrm{~m} \mathrm{x8} \mathrm{m} \mathrm{and}$ sugarcane variety was CoS-767. The different machine performance and crop parameters were taken during the field operations which are discussed below:

\section{Seed rate (kg/ha)}

The weight of setts dropped in $5 \mathrm{~m}$ length was determined by physical balance. The seed rate, $\mathrm{kg} / \mathrm{ha}$ was calculated as follows:

Seed rate,$\frac{\mathrm{kg}}{\mathrm{ha}}=\frac{\text { Quantity of seed droped in } 5 \mathrm{~m}(\mathrm{~kg})}{5 \times 0.75} \times 100 \times 100$

$=$ Quantity of seed dropped in 5m/ kg x2666.7

Depth of planting $(\mathrm{cm})$

Effective field capacity (ha/h)

Field efficiency

\section{Results and Discussion}

\section{Effect of irrigation}

Results of the experiment from Table 1 revealed that non significantly the highest value was observed in treatment effect of the irrigation on the viz., for both pre-planting and post planting irrigation on effective field capacity $(0.23$ and $0.23 \mathrm{ha} / \mathrm{h})$ and Field efficiency $(56.04 \%$ and $55.80 \%)$ is maximum for post planting irrigation at 2014-15 and 2015-16. Seed rate (kg/ha) (6116.30 and 6102.73) and Depth of planting (21.32 and $21.32 \mathrm{~cm}$ ) was minimum for post planting irrigation at 2014-15 and 2015-16. However, seed rate, depth of planting, effective field capacity and field efficiency has nonsignificant effect on pre planting irrigation and post planting irrigation during 2014-15 and 2015-16.

\section{Effect of planter}

Results of the experiment from Table 1 revealed that significantly the highest value was observed in treatment effect of the planter for Ridger sugarcane cutter planter viz., that the Effective field capacity (0.27 and 0.27 ha/h), Field efficiency (58.63\% and 58.27\%) at 2014-15 and 2015-16. 
Table.1 Response of irrigation, planters and tillage on seed rate $(\mathrm{kg} / \mathrm{ha})$, depth of planting $(\mathrm{cm})$, effective field capacity (ha/h) and field efficiency of sugarcane

\begin{tabular}{|c|c|c|c|c|c|c|c|c|c|}
\hline \multirow{2}{*}{\multicolumn{2}{|c|}{ Treatments }} & \multicolumn{2}{|c|}{ Seed rate $(\mathrm{kg} / \mathrm{ha})$} & \multicolumn{2}{|c|}{ Depth of planting $(\mathrm{cm})$} & \multicolumn{2}{|c|}{ Effective field capacity (ha/h) } & \multicolumn{2}{|c|}{ Field efficiency (\%) } \\
\hline & & 2014-15 & 2015-16 & 2014-15 & 2015-16 & 2014-15 & 2015-16 & 2014-15 & 2015-16 \\
\hline \multicolumn{10}{|c|}{ Irrigations (I) } \\
\hline$I_{1}$ & Pre- planting irrigation & 6120.47 & 6094.77 & 21.33 & 21.33 & 0.23 & 0.23 & 55.89 & 55.66 \\
\hline \multirow[t]{4}{*}{$I_{2}$} & Post-planting irrigation & 6116.30 & 6102.73 & 21.32 & 21.32 & 0.23 & 0.23 & 56.04 & 55.80 \\
\hline & F-test & NS & NS & NS & NS & NS & NS & NS & NS \\
\hline & S. Ed. $( \pm)$ & 133.32 & 96.52 & 1.04 & 1.02 & 0.01 & 0.02 & 1.89 & 1.96 \\
\hline & C. D. $(P=0.05)$ & - & - & - & - & - & - & - & - \\
\hline \multicolumn{10}{|c|}{ Planters (P) } \\
\hline $\mathbf{P}_{0}$ & $\begin{array}{l}\text { Conventional practice (Tractor operated ridger) } \\
\text { (control) }\end{array}$ & 5876.83 & 5802.42 & 21.27 & 21.26 & 0.10 & 0.10 & 47.13 & 46.33 \\
\hline $\mathbf{P}_{1}$ & Disc type sugarcane cutter planter & 6191.00 & 6183.33 & 21.36 & 21.35 & 0.26 & 0.26 & 58.13 & 58.13 \\
\hline $\mathbf{P}_{2}$ & Slit type sugarcane cutter planter & 6163.92 & 6160.00 & 21.34 & 21.34 & 0.26 & 0.26 & 57.90 & 57.88 \\
\hline $\mathbf{P}_{3}$ & Ridger sugarcane cutter planter & 6198.67 & 6181.00 & 21.33 & 21.34 & 0.27 & 0.27 & 58.63 & 58.27 \\
\hline $\mathbf{P}_{4}$ & Furrower sugarcane cutter planter & 6161.50 & 6167.00 & 21.33 & 21.33 & 0.26 & 0.26 & 58.04 & 58.03 \\
\hline \multicolumn{2}{|c|}{ F-test } & $\mathrm{S}$ & $\mathrm{S}$ & NS & NS & $\mathrm{S}$ & $\mathrm{S}$ & $\mathrm{S}$ & $\mathrm{S}$ \\
\hline \multicolumn{2}{|c|}{ S. Ed. $( \pm)$} & 84.32 & 61.04 & 0.65 & 0.65 & 0.01 & 0.01 & 1.20 & 1.24 \\
\hline \multicolumn{2}{|c|}{ C. D. $(P=0.05)$} & 241.39 & 174.76 & - & - & 0.02 & 0.03 & 3.43 & 3.56 \\
\hline \multicolumn{10}{|c|}{ Tillage (T) } \\
\hline$T_{1}$ & Conventional tillage (1ploughing +2 harrowing) & 6122.30 & 6107.03 & 21.32 & 21.33 & 0.23 & 0.23 & 55.88 & 55.73 \\
\hline $\mathbf{T}_{2}$ & Tillage operation by rotary tiller(2 rotavator) & 6114.47 & 6090.47 & 21.33 & 21.33 & 0.23 & 0.23 & 56.05 & 55.73 \\
\hline \multicolumn{2}{|c|}{ F-test } & NS & NS & NS & NS & NS & NS & NS & NS \\
\hline \multicolumn{2}{|c|}{ S. Ed. $( \pm)$} & 133.32 & 96.52 & 1.04 & 1.02 & 0.01 & 0.02 & 1.89 & 1.96 \\
\hline \multicolumn{2}{|c|}{ C. D. $(P=0.05)$} & - & - & - & - & - & - & - & - \\
\hline \multicolumn{10}{|c|}{ Interaction (PxI) } \\
\hline \multicolumn{2}{|c|}{ F-test } & NS & NS & NS & NS & NS & NS & NS & NS \\
\hline \multicolumn{2}{|c|}{ S. Ed. $( \pm)$} & 59.62 & 43.16 & 0.46 & 0.46 & 0.01 & 0.01 & 0.85 & 0.88 \\
\hline \multicolumn{2}{|c|}{ C. D. $(P=0.05)$} & - & - & - & - & - & - & - & - \\
\hline \multicolumn{10}{|c|}{ Interaction (PxT) } \\
\hline \multicolumn{2}{|c|}{ F-test } & NS & NS & NS & NS & $\mathrm{S}$ & NS & $\mathrm{S}$ & NS \\
\hline \multicolumn{2}{|c|}{ S. Ed. $( \pm)$} & 73.02 & 52.86 & 0.57 & 0.56 & 0.01 & 0.01 & 1.04 & 1.08 \\
\hline \multicolumn{2}{|c|}{ C. D. $(P=0.05)$} & - & - & - & - & 0.02 & - & 2.97 & - \\
\hline \multicolumn{10}{|c|}{ Interaction (IxT) } \\
\hline \multicolumn{2}{|c|}{ F-test } & S & S & S & $\mathrm{S}$ & $\mathrm{S}$ & $\mathrm{S}$ & $\mathrm{S}$ & $\mathrm{S}$ \\
\hline \multicolumn{2}{|c|}{ S. Ed. $( \pm)$} & 94.27 & 68.25 & 0.73 & 0.72 & 0.01 & 0.01 & 1.34 & 1.39 \\
\hline \multicolumn{2}{|c|}{ C. D. $(P=0.05)$} & 269.89 & 195.39 & 2.10 & 2.07 & 0.03 & 0.03 & 3.83 & 3.98 \\
\hline
\end{tabular}


Table.2 Interaction effect of irrigation, planters and tillage on seed rate $(\mathrm{kg} / \mathrm{ha})$, depth of planting $(\mathrm{cm})$, effective field capacity (ha/h) and field efficiency of sugarcane

\begin{tabular}{|c|c|c|c|c|c|c|c|c|c|}
\hline \multicolumn{2}{|c|}{ Treatments } & \multicolumn{2}{|c|}{ Seed rate $(\mathrm{kg} / \mathrm{ha})$} & \multicolumn{2}{|c|}{ Depth of planting (cm) } & \multicolumn{2}{|c|}{ Effective field capacity (ha/h) } & \multicolumn{2}{|c|}{ Field efficiency $(\%)$} \\
\hline & & 2014-15 & 2015-16 & 2014-15 & 2015-16 & 2014-15 & 2015-16 & 2014-15 & 2015-16 \\
\hline $\mathrm{T}_{1}$ & $\mathrm{I}_{1} \mathrm{P}_{0} \mathrm{~T}_{1}$ & 5918.33 & 5802.67 & 21.50 & 21.50 & 0.10 & 0.10 & 45.97 & 45.43 \\
\hline $\mathbf{T}_{2}$ & $\mathrm{I}_{1} \mathrm{P}_{0} \mathrm{~T}_{2}$ & 5860.67 & 5791.67 & 21.10 & 21.10 & 0.11 & 0.11 & 48.53 & 48.23 \\
\hline $\mathbf{T}_{3}$ & $\mathrm{I}_{1} \mathrm{P}_{1} \mathrm{~T}_{1}$ & 6189.00 & 6173.33 & 21.23 & 21.25 & 0.27 & 0.27 & 58.80 & 58.13 \\
\hline $\mathbf{T}_{4}$ & $\mathrm{I}_{1} \mathrm{P}_{1} \mathrm{~T}_{2}$ & 6192.00 & 6193.33 & 21.67 & 21.67 & 0.26 & 0.26 & 58.37 & 57.60 \\
\hline $\mathbf{T}_{5}$ & $\mathrm{I}_{1} \mathrm{P}_{2} \mathrm{~T}_{1}$ & 6178.67 & 6180.00 & 20.97 & 20.97 & 0.27 & 0.27 & 58.03 & 57.77 \\
\hline $\mathbf{T}_{6}$ & $\mathrm{I}_{1} \mathrm{P}_{2} \mathrm{~T}_{2}$ & 6117.00 & 6121.67 & 21.57 & 21.58 & 0.26 & 0.26 & 56.87 & 57.07 \\
\hline $\mathbf{T}_{7}$ & $\mathrm{I}_{1} \mathrm{P}_{3} \mathrm{~T}_{1}$ & 6227.33 & 6210.00 & 21.23 & 21.23 & 0.27 & 0.27 & 58.93 & 58.93 \\
\hline $\mathbf{T}_{8}$ & $\mathrm{I}_{1} \mathrm{P}_{3} \mathrm{~T}_{2}$ & 6204.00 & 6152.33 & 21.07 & 21.07 & 0.26 & 0.26 & 57.03 & 57.03 \\
\hline $\mathbf{T}_{9}$ & $\mathrm{I}_{1} \mathrm{P}_{4} \mathrm{~T}_{1}$ & 6195.67 & 6197.33 & 21.50 & 21.50 & 0.27 & 0.27 & 58.47 & 58.47 \\
\hline $\mathbf{T}_{10}$ & $\mathrm{I}_{1} \mathrm{P}_{4} \mathrm{~T}_{2}$ & 6122.00 & 6125.33 & 21.47 & 21.47 & 0.26 & 0.26 & 57.90 & 57.90 \\
\hline $\mathbf{T}_{11}$ & $\mathrm{I}_{2} \mathrm{P}_{0} \mathrm{~T}_{1}$ & 5841.67 & 5843.33 & 21.50 & 21.49 & 0.10 & 0.10 & 45.97 & 45.97 \\
\hline $\mathbf{T}_{12}$ & $\mathrm{I}_{2} \mathrm{P}_{0} \mathrm{~T}_{2}$ & 5886.67 & 5772.00 & 20.97 & 20.97 & 0.11 & 0.10 & 48.03 & 45.70 \\
\hline $\mathbf{T}_{13}$ & $\mathrm{I}_{2} \mathrm{P}_{1} \mathrm{~T}_{1}$ & 6189.00 & 6173.33 & 21.27 & 21.26 & 0.26 & 0.26 & 58.81 & 58.80 \\
\hline$T_{14}$ & $\mathrm{I}_{2} \mathrm{P}_{1} \mathrm{~T}_{2}$ & 6194.00 & 6193.33 & 21.25 & 21.23 & 0.26 & 0.26 & 58.53 & 58.53 \\
\hline$T_{15}$ & $\mathrm{I}_{2} \mathrm{P}_{2} \mathrm{~T}_{1}$ & 6164.33 & 6144.33 & 21.33 & 21.33 & 0.27 & 0.27 & 58.23 & 58.23 \\
\hline $\mathrm{T}_{16}$ & $\mathrm{I}_{2} \mathrm{P}_{2} \mathrm{~T}_{2}$ & 6195.67 & 6194.00 & 21.50 & 21.48 & 0.26 & 0.26 & 58.48 & 58.47 \\
\hline $\mathbf{T}_{17}$ & $\mathrm{I}_{2} \mathrm{P}_{3} \mathrm{~T}_{1}$ & 6180.00 & 6180.00 & 21.49 & 21.52 & 0.26 & 0.26 & 58.30 & 58.30 \\
\hline $\mathbf{T}_{18}$ & $\mathrm{I}_{2} \mathrm{P}_{3} \mathrm{~T}_{2}$ & 6183.33 & 6181.67 & 21.53 & 21.53 & 0.27 & 0.27 & 58.27 & 58.27 \\
\hline$T_{19}$ & $\mathrm{I}_{2} \mathrm{P}_{4} \mathrm{~T}_{1}$ & 6139.00 & 6166.00 & 21.20 & 21.20 & 0.26 & 0.26 & 57.27 & 57.27 \\
\hline $\mathbf{T}_{20}$ & $\mathrm{I}_{2} \mathrm{P}_{4} \mathrm{~T}_{2}$ & 6189.33 & 6179.33 & 21.17 & 21.17 & 0.27 & 0.27 & 58.53 & 58.48 \\
\hline \multicolumn{10}{|c|}{ Interaction (PxIxT) } \\
\hline \multicolumn{2}{|c|}{ F-test } & NS & NS & NS & NS & $\mathrm{S}$ & NS & $\mathrm{S}$ & $\mathrm{S}$ \\
\hline \multicolumn{2}{|c|}{ S. Ed. ( \pm$)$} & 42.16 & 30.52 & 0.33 & 0.32 & 0.00 & 0.00 & 0.60 & 0.62 \\
\hline \multicolumn{2}{|c|}{ C. D. $(P=0.05)$} & - & - & - & - & 0.01 & - & 1.71 & 1.78 \\
\hline
\end{tabular}


Seed rate $(\mathrm{kg} / \mathrm{ha})(5876.83$ and 5802.42) and Depth of planting $(21.27$ and $21.26 \mathrm{~cm}$ ) was minimum for Conventional practice (Tractor operated ridger) (control) at 2014-15 and 2015-16. However, non significantly the highest value of depth of planting (21.36 and 21.35) during 2014-15 and 2015-16.

This may be due to sugarcane coming directly in contact with blade center. In this design, cutting was smooth as evident from clean cut obtained. The planters, there is a need to standardize pattern of placement of sugarcane in the field which may be at ends middle or both depending on length of plot and size of cane hopper in the machine. This is needed in order to maximize the actual seed rates of the machine.

With the advent of sugarcane cutter planters on the scene, where cutting of whole cane into setts is also done simultaneously, planting through machine has become a viable proposition. Ridger type, Disc type sugarcane cutter planters have been developed and successfully tested and demonstrated in the farmers' fields (Singh and Singh, 2006) (Singh et al., 2011).

\section{Effect of tillage}

Results of the experiment from Table 1 revealed that non significantly the highest value was observed in treatment effect of the tillage on the viz., for both Conventional tillage (1ploughing +2 harrowing) and Tillage operation by rotary tiller ( 2 rotavator) on effective field capacity $(0.23$ and 0.23 $\mathrm{ha} / \mathrm{h})$ and Field efficiency $(56.05 \%$ and $55.73 \%$ ) was maximum for Tillage operation by rotary tiller (2 rotavator) at $2014-15$ and 2015-16. Seed rate (kg/ha) (6114.47 and 6090.47) and Depth of planting (21.33 and $21.33 \mathrm{~cm}$ ) was minimum for Tillage operation by rotary tiller ( 2 rotavator) in 2014-15 and 2015-16. However, seed rate, depth of planting, effective field capacity and field efficiency has non-significant effect on Conventional tillage (1ploughing +2 harrowing) and Tillage operation by rotary tiller (2 rotavator) during 2014-15 and 201516.

\section{Interaction effect}

A perusal of the data from Table 1 and 2 on seed rate $(\mathrm{kg} / \mathrm{ha})$, depth of planting $(\mathrm{cm})$, effective field capacity (ha/h) and field efficiency of non-significantly during both years by interaction effect of planters with irrigation (PxI) and planters with tillage (PxT) and significantly the highest in interaction of irrigation and tillage (IxT). However, effective field capacity and field efficiency significantly higher during first years by interaction effect of planters with irrigation (PxT) and seed rate, depth of planting, effective field capacity and field efficiency significantly higher during both years by interaction effect of irrigation with planters (IxT).

It is also clear that from the data which found interaction effect of planters with irrigation and tillage (PxIxT) in both years. The highest value found viz., seed rate (kg/ha) (6227.33and 6210.00), treatment $\left(\mathrm{T}_{7}\right) \mathrm{I}_{1} \mathrm{P}_{3} \mathrm{~T}_{1}$ Pre- planting irrigation + Ridger sugarcane cutter planter + Conventional tillage (1ploughing +2 harrowing) during the years 2014-15 and 2015-16, respectively.

However, depth of planting (21.67 and 21.67 $\mathrm{cm}$ ) during both of the year in treatment $\mathrm{I}_{1} \mathrm{P}_{1} \mathrm{~T}_{2}\left(\mathrm{~T}_{4}\right)$ Pre- planting irrigation + Disc sugarcane cutter planter + Tillage operation by rotary tiller (2 rotavator), effective field capacity (ha/h) (0.27 and 0.27$)$ during both of the year in treatment $\left(\mathrm{T}_{7}\right) \mathrm{I}_{1} \mathrm{P}_{3} \mathrm{~T}_{1}$ Pre- planting irrigation + Ridger sugarcane cutter planter + Conventional tillage (1ploughing +2 harrowing), and field efficiency (58.93 and 
$58.93 \%$ ) during both of the year in treatment $\left(\mathrm{T}_{7}\right) \mathrm{I}_{1} \mathrm{P}_{3} \mathrm{~T}_{1}$ Pre- planting irrigation + Ridger sugarcane cutter planter + Conventional tillage (1ploughing +2 harrowing), respectively.

After the analysis of the different treatment of the sugarcane production with the consideration of two irrigation planting field conditions (pre and post- planting irrigation), two tillage (Conventional tillage (1ploughing +2 harrowing) and Tillage operation by rotary tiller (2 rotavator)), Conventional practice (Tractor operated ridger) (control) and different planter for two years. The maximum treatment effect of the effective field capacity and field efficiency of sugarcane in the Ridger sugarcane cutter planter was found during the years in comparison of the other planters.

Maximum treatment effect of the field efficiency was found (58.63 and 58.275\%) during both year 2014-15 and 2015-16 respectively for Ridger sugarcane cutter planter. Seed rate and depth of planting was minimum for post planting irrigation and Tillage operation by rotary tiller ( 2 rotavator) during both year 2014-15 and 2015-16. Effective field capacity and field efficiency was maximum for post planting irrigation and Tillage operation by rotary tiller ( 2 rotavator) during both year 2014-15 and 2015-16.

\section{Acknowledgements}

Authors express thanks to anonymous reviewers for exhaustive review and constructive comments that helped us lot in improving the manuscript. We gratefully acknowledge the efforts of Dr. Ashok Tripathi, Professor\& Head, Department of Farm Machinery and Power Engineering, Sam Higginbottom University of Agriculture, Technology and Sciences, Allahabad 211007, U.P. (India).

\section{References}

Anon. 2000. AICRP on Ergonomics and Safety in Agriculture (Leaflet), CIAE, Bhopal, India.

Anonymous. 1999. Indian sugar. The Indian Sugar Mills Association. XL: 475-476.

Anonymous. 2001. Indian sugar. The Indian Sugar Mills Association. XLIX: 222224.

Anonymous.1977. Extending crushing season of sugar cane. Annual Report Indian Institute of Sugarcane Research. Lucknow. pp. 11-13.

Anonymous.2001. Productivity constraints. The Hindu Survey of Indian Agriculture. pp. 97-102.

Bell, M. J., Halpin, N. V., Garside, A. L., Moody, P. W., Stirling, G. R. and Robotham, B. J. 2003. Evaluating combinations of fallow management, controlled traffic and tillage options in prototype sugarcane farming systems at Bundaberg Proc. Aust. Soc. Sugar Cane Technol. 25.

Chaorakam, Isara, Anek Sukcharoen Thanankorn Jaiphong 2012. Field Evaluation of Subsoiling and Liquid Fertilizer Injection for Minimum Tillage of Sugarcane Planter (Part 1) -Effects of Subsoiling and Liquid Fertilizer Injection on Germination Test. International Journal of Applied Science and Technology, (2) 7

Kladivk, S., 2001. Soil acidification and potassium leaching in northeast Thailand. In: Proceedings of Second International Conference on Land Degradation, KhonKaen, Thailand, pp. 25-29.

Kumar Manish, Tripathi Ashok, 2015. "To Study of the Different Modes of Tillage for the Performance of Sugarcane Cutter Planter". International Research Journal of Engineering and Technology 
(IRJET) Volume: 02 Issue: 03 | June2015.

Kumar Manish, Tripathi Ashok, 2017. "Study of the Different Types of Sugarcane Planter in India". IOSR- Journal of Agriculture and Veterinary science (JAVS), Vol. 10(7), PP 01-07 | ISSN: 2319-2380.

Kumar Manish, Tripathi Ashok, D'souza M Prashant. and Kumar Devesh, 2017, A study on the performance on productivity of sugarcane crop with different combination of tillage operations, International journal of agricultural engineering. Vol. 10, Issue 2, Page No. 340-346.

Kumar Manish, Tripathi Ashok, Kumar Devesh and Kumar Sumit, 2017, Study of the Effect of Pre and Post Irrigation on Different Tillage Treatments for Different Planter on Soil's Physical Properties, International journal of agricultural engineering. Vol. 10, Issue 2, Page No. 409-415.

Kumar, Manoj Patel, H.K. Patel, C.N. Umale A.A. and Patel J.J. 2015 b: Varietal response of summer cluster bean (Cymopsis tetragonoloba L.) to different irrigation scheduling (IW: CPE ratios) under middle Gujarat conditions., Eco. Env. \& Cons. 21 (S159-S163).

Kumar, Manoj., Patel, J.J., Umale, Aniket., Prasad, Ram. Dulare and Patel, H. K. 2015 a: Performance of cultivar and irrigation scheduling (IW: CPE ratio) on yield, water use efficiency, consumptive use of water and economics of summer clusterbean (Cymopsis tetragonoloba L.) under middle Gujarat conditions, Res. Environ. Life Sci., 8: 599-602

Lavelle, R., 2000. Introductory remarks. In: Horn, R., van den Akker, J.J., Arvidson, J. (Eds.), Subsoil Compaction: Distribution, Processes and
Consequences, Advances in Geoecology, 33, 32-43.

Mandal, C. R. and Manji, R. K. 2008. Role of Japan in promotion of agricultural mechanization in India. Agricultural Mechanization in Asia. America and Latin America, 44(4): 15-17.

Maraddi E 2008. Agricultural Machinery Costing Methods and Standards. Published by South African Sugarcane Research Institute, Mount Edgecombe, South Africa.

Muhammad Ashraf, Muhammad Shafi Sabir, Manzoor Ahmed and Muhammad Younis. 2003. Effects of different tillage systems on bulk density and sugarcane yield. Pakistan Journal of Life and Social Sciences. 1(1): 69-71.

Pawar S. and Bukhtar. R. 2011. Performance Feasibility and Economic Viability of Sugarcane Planter in Western Plane Zone of Uttar Pradesh, India, Sugar Tech(2): 101-108.

Ramesh P (2000) Effect of different levels of drought during the formative phase on growth parameters and its relationship with dry matter accumulation in sugarcane. Sugarcane Breeding Institute, Coimbatore, India. J. Agron. Crop Sci., 185: 83-89.

Salunkhe JN, Bhoyal J, and Tiwari AL. 2001. Development and modification of machinery for an improved farming system in the Australian sugar industry. Proc IntSocSug Cane Technol26: 103113.

Sharma M.P., Singh, J. and Singh A. K. 1995. Mechanization of Sugarcane Cultivation in India, Sugar Tech., 04(4): 310-314

Singh J P and Dixit O N (1989) Improved IISR bullock drawn sugarcane planter Indian Society of Agricultural Engineering. Paper no. 80-123.

Singh M. A. and Singh S. 2006: Response of sugarcane canopy development to water 
stresses. Field Crops Research, 98: 9197.

Vachaparampil K. N, P., 1999. The effects of long term conservation tillage, crop residues and $\mathrm{P}$ fertilizer on soil condition and responses of summer and winter crops on an Andosol in South
Inda. Soil \& Tillage Research, 89 (2), 167-176

Yadav, R.N.S., Singh P. and Choudhuri, D. (2001). Mechanization scenario of sugarcane cultivation in India. Paper Presented at 35th annual convention and national symposium of ISAE held at OUAT Bhubaneshwar.

\section{How to cite this article:}

Manish Kumar, Ashok Tripathi and Mrinal Verma. 2018. Study of the Effect of Different Irrigation and Conservation Tillage Practices on the Performance of Different Sugarcane Planter under NWPZ Conditions. Int.J.Curr.Microbiol.App.Sci. 7(05): 3251-3259.

doi: https://doi.org/10.20546/ijcmas.2018.705.380 